\title{
Freshwater mollusc assemblages and habitat associations in the Danube River drainage, Hungary
}

\author{
ERIKA BÓDIS ${ }^{\mathrm{a}, *}$, BENCE TÓTH $^{\mathrm{a}}$ and RONALDO SOUSA ${ }^{\mathrm{b}, \mathrm{c}}$ \\ ${ }^{\mathrm{a}}$ MTA Centre for Ecological Research, Danube Research Institute, Karolina, Budapest, Hungary \\ ${ }^{\mathrm{b}}$ Interdisciplinary Centre of Marine and Environmental Research (CIIMAR/CIMAR), University of Porto, Porto, Portugal \\ ${ }^{\mathrm{c}}$ CBMA - Centre of Molecular and Environmental Biology, Department of Biology, University of Minho, Braga, Portugal
}

\begin{abstract}
1. Native freshwater mollusc diversity has been declining over the past decades. For developing efficient conservation management plans for molluses, it is especially important to identify areas with high native biodiversity.

2. The River Danube is one of the most important freshwater ecosystems in Europe and should receive special attention. The main objective of this work was to characterize the composition, diversity and conservation status of freshwater molluscs occurring in the Hungarian Danube River Drainage in five river habitat types (main channel of the Rivers Danube and Tisza, side channels of River Danube, tributaries of Rivers Danube and Tisza).

3. In total, 53 mollusc species were identified including 10 invasive species and 12 species of conservation concern. The main determining factors of mollusc composition were sediment characteristics, current velocity and oxygen content. Nitrate-nitrogen, ammonium-nitrogen, and calcium content also play a key role.

4. Overall, density, species richness and diversity showed significant differences between habitat types. The highest diversity values were detected in the side channels, but the highest proportion of threatened species was observed in the tributaries. The highest number and proportion of invasive species was detected in the main channel of the Danube. Most of the recorded invasive species were previously documented in side channels and the adjacent wetlands, but did not invade the tributaries.

5. Tributaries may provide refuges for native molluscs and could be considered as 'source' populations, which may be critically important in the regional maintenance of threatened species. Tributaries are still less disturbed and less invaded; and should be given priority in future conservation management plans.
\end{abstract}

Copyright (C) 2015 John Wiley \& Sons, Ltd.

Received 10 November 2014; Revised 10 May 2015; Accepted 22 July 2015

KEY WORDS: biodiversity; conservation evaluation; endangered and invasive species; Bivalvia; Gastropoda; River Danube

\footnotetext{
*Correspondence to: Erika Bódis, MTA Centre for Ecological Research, Danube Research Institute, Karolina út 29-31, 1113, Budapest, Hungary. Email: bodiserk@gmail.com
} 


\section{INTRODUCTION}

Global freshwater biodiversity is experiencing far greater declines than terrestrial or marine ecosystems (McAllister et al., 1997; Dudgeon et al., 2006; Strayer and Dudgeon, 2010). For example, future extinction rates of freshwater faunal species in North America are predicted to be five times higher than for terrestrial fauna (Ricciardi and Rasmussen, 1999). Freshwater ecosystems are extremely threatened and their conservation is very difficult since they have high levels of endemism owing to natural isolation, catchment division and presence of saltwater barriers which impair re-colonization. In addition, they have a special landscape position as receivers being affected by all the changes and disturbances from adjacent terrestrial areas (Carpenter et al., 2011). Moreover, rivers are open, directional systems, and many species migrate longitudinally or laterally by using different habitats during their life cycle, which may be significantly altered by human activities and makes the implementation of management and conservation measures especially difficult (Dudgeon et al., 2006). Therefore, if freshwater species, declines continue at current rates, and the human demands for water remain constant, the opportunity to conserve freshwater biodiversity may disappear (Dudgeon et al., 2006; Vörösmarty et al., 2010).

All organisms are ultimately affected by human perturbations but freshwater molluscs are especially sensitive to anthropogenic and climatic disturbances (e.g. habitat loss and degradation, pollution, introduction of invasive species, floods, droughts), and species loss has accelerated over the past decades (Régnier et al., 2009). Moreover, freshwater bivalves belonging to the family Unionidae are considered one of the most endangered groups of animals, and many populations are regionally or globally in decline (Bogan, 1993; Lydeard et al., 2004; Burlakova et al., 2011a, b; Lopes-Lima et al., 2014). Since freshwater molluscs are involved in several key ecosystem functions and services (Rosemond et al., 1993; Strayer et al., 1999; Vaughn and Hakenkamp, 2001; Gutiérrez et al., 2003; Spooner and Vaughn, 2008; Spooner et al., 2012; Strayer, 2014; Tolley-Jordan et al., 2015) their continued decline can result in cascading effects that may alter the whole ecosystem. Despite their central ecological role, studies dealing with their distribution and diversity patterns in large river systems are insufficient.

Although many freshwater ecosystems have undergone declines in native diversity they have also experienced the introduction of many invasive species (Sousa et al., 2014). The River Danube, one of the most important shipping routes in Europe, is a good example (Bódis et al., 2012a). Some invasive mollusc species deserve special attention since they can dominate the benthic community in density and biomass triggering significant changes in the structure and functioning of freshwater ecosystems (Strayer et al., 1999; Sousa et al., 2009, 2011, 2014). In the Danube River Basin the Asian clam, Corbicula fluminea and the Chinese pond mussel, Sinanodonta woodiana became dominant in a short period of time and may impair the conservation of native molluscs (Bódis et al., 2011, 2012a, b, 2014a, b).

If conservation priorities are to be set, and efficient conservation management plans put in place it is important to monitor the distribution and diversity of freshwater molluscs regularly and follow up the changes in the range and population size of threatened and invasive species. The River Danube is one of the most important freshwater ecosystems in Europe and should receive special attention. The main objectives of this work were to characterize the composition, diversity and conservation status of freshwater molluscs in the Hungarian Danube River Drainage, in five different habitat types (main channel of the rivers Danube and Tisza, side channels of the Danube, tributaries of the rivers Danube and Tisza) and to determine the principal environmental variables influencing the composition of the mollusc assemblages. This information may provide reference data to assess future changes to the molluscan assemblages and to guide the management measures that need to be applied to the conservation of key native species or problematic invasive species.

\section{MATERIAL AND METHODS}

\section{Study area}

The Danube is the longest river $(2857 \mathrm{~km})$ in Central Europe. It has a catchment area of 
$817000 \mathrm{~km}^{2}\left(39000 \mathrm{~km}^{2}\right.$ in Hungary) and receives all of the running waters of Hungary in a length of $417 \mathrm{~km}$. Its average annual discharge is approximately $2350 \mathrm{~m}^{3} \mathrm{~s}^{-1}$ at Budapest (Töry, 1952). The River Tisza is one of the main rivers in Central Europe, and has the largest catchment and length among the Danube tributaries. The Tisza drains an area of $157135 \mathrm{~km}^{2}\left(47000 \mathrm{~km}^{2}\right.$ in Hungary) and has a length of $966 \mathrm{~km}$. With an average annual discharge of $820 \mathrm{~m}^{3} \mathrm{~s}^{-1}$ at Szeged, its contribution to the Danube is about $13 \%$ (Alföldi and Schweitzer, 2003). The River Rába is a tributary of the Danube comprising a total basin area of $10113 \mathrm{~km}^{2}$, a length of $283 \mathrm{~km}$ and an average annual discharge of $27 \mathrm{~m}^{3} \mathrm{~s}^{-1}$ at Györ. The River Ipoly is the largest tributary on the left side of the Hungarian Danube section with a length of $212 \mathrm{~km}$, a catchment area of $5108 \mathrm{~km}^{2}(143 \mathrm{~km}$, $1518 \mathrm{~km}^{2}$ in Hungary) and an average annual discharge of $21 \mathrm{~m}^{3} \mathrm{~s}^{-1}$. The River Bodrog is a tributary of the River Tisza and has a length of $65 \mathrm{~km}(15 \mathrm{~km}$ in Slovakia, $50 \mathrm{~km}$ in Hungary). Its catchment area is $13579 \mathrm{~km}^{2}\left(972 \mathrm{~km}^{2}\right.$ in Hungary) and its average annual discharge is $115 \mathrm{~m}^{3} \mathrm{~s}^{-1}$.

Three side channels connected with the Danube were also investigated. The Mosoni-Danube, the longest side channel with a length of $121.5 \mathrm{~km}$ in
Hungary, is located in the wetland of Szigetköz. In general, the Szigetköz has a very high conservation value and is usually considered a pristine area. However, hydrological changes caused by the Gabcikovo hydropower plant have affected the faunal assemblages (Nosek et al. 2007; Bódis et al. 2008). The Ráckevei-(Soroksári)-Danube has a length of $57.3 \mathrm{~km}$, and has a regulated water discharge through the Kvassay water-gate with anthropogenically disturbed habitats. The side channel at Göd is short, and during low water levels in the Danube (approximately $125 \mathrm{~cm}$ at Vác) its northern connection with the main channel is interrupted so that for $45 \%$ of the year the water flow ceases in the side channel.

\section{Sampling methods}

Sampling sites (35 in total) were located in the main channel of the River Danube (D1-6); in the side channels of the River Danube: Mosoni-Danube (MD1-3), Göd (SD1), Ráckevei-(Soroksári)-Danube (SD2-3); in the tributaries of the River Danube: River Rába (R1-3), River Ipoly (I1-8); in the main channel of the River Tisza (T1-6); and in the tributary of the River Tisza: River Bodrog (B1-6) (Figure 1). The sampling sites of the Danube were

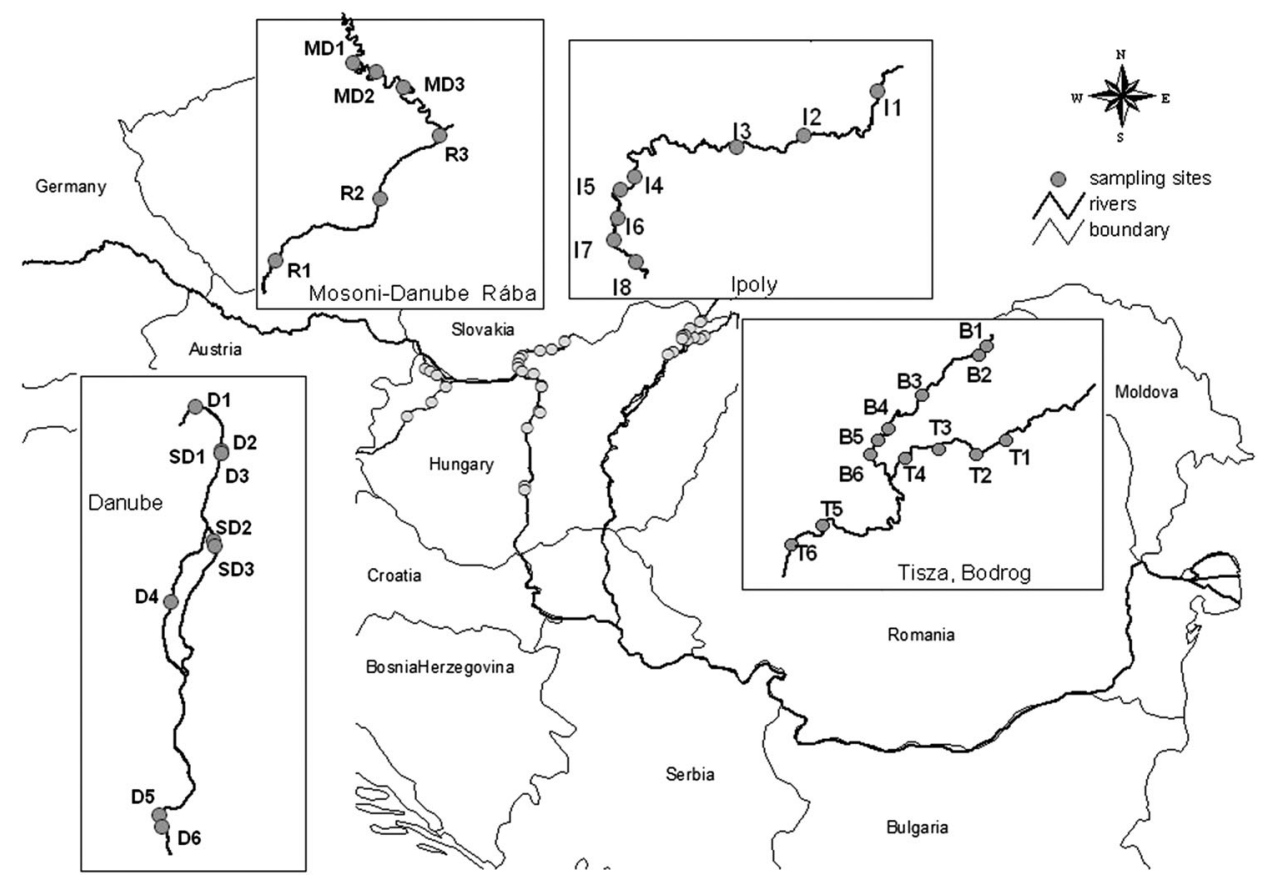

Figure 1. Map of sampling sites. 
chosen based on previous studies (Bódis et al., 2008; Nosek and Oertel, 2008) to represent both depositive and erosional parts of the main channel upstream and downstream to Budapest and the different types of side channels. The sampling sites in the tributaries were evenly distributed throughout the length of the rivers.

Quantitative samples of bottom sediment were collected in the main and side channels of the Danube seasonally in 2007 and 2008, and in the River Tisza and the tributaries (River Rába, River Ipoly, River Bodrog) in 2011 and 2012. A hand net was used, $25 \mathrm{~cm}$ wide and with a mesh size of $500 \mu \mathrm{m}$. At each sampling site four replicates with an area of $0.5 \mathrm{~m}^{2}$ were taken randomly within a longitudinal section of $10-15 \mathrm{~m}$. To assess the density of large unionids in the River Tisza and tributaries, where large populations were detected, 15 randomly placed $0.25 \mathrm{~m}^{2}$ quadrats were searched visually in the littoral zone at a water depth of $1 \mathrm{~m}$. Samples were fixed in situ in $70 \%$ Patosolv solution and in the laboratory animals were identified and preserved in $70 \%$ ethanol. Nomenclature follows the Checklist of the European Continental Mollusca (Falkner et al., 2001) and the catalogue of Fehér and Gubányi (2001) that reflects the Hungarian situation. Conservation status of species in Hungary was assigned with reference to the work of Fehér et al. (2006) and in Europe with reference to the IUCN Red List (IUCN, 2001) and the DAISIE database.

In the River Tisza and tributaries, where the substrate and water flow were relatively homogeneous, environmental variables were measured only from the water column (conductivity, $\mathrm{pH}$, dissolved oxygen, chlorophyll-a, $\left.\mathrm{Ca}, \mathrm{NO}_{3}-\mathrm{N}, \mathrm{NH}_{4}-\mathrm{N}, \mathrm{PO}_{4}-\mathrm{P}\right)$. In the main and side channels of the Danube, where the environment was heterogeneous in terms of substrate and water flow, included a diverse range of habitats, environmental variables were measured seasonally. Sediment samples were collected to assess granulometry using the following fractions of sediment: coarse $(\mathrm{C}, \quad 2360>750 \mu \mathrm{m})$, fine $(\mathrm{F}, 750>250 \mu \mathrm{m})$, very fine $(\mathrm{V}, 250>63 \mu \mathrm{m})$ and ultra fine $(\mathrm{U}, 63>0.45 \mu \mathrm{m})$ and benthic organic matter (BOM) content of the sediment was measured according to the fractions of sediment (CBOM,
FBOM, VBOM, UBOM)). In the water column measurements were made of temperature, conductivity, redox potential, $\mathrm{pH}$, dissolved oxygen, chlorophyll-a and current velocity. A detailed description of the methods and environmental parameters measured are presented in Bódis et al., 2011, 2012b. In order to characterize the habitat types and compare the sampling sites the environmental data set of the National Inspectorate for Environment was used, which is based on monthly sampling.

\section{Data analysis}

One-way nonparametric multivariate analyses of variance (one-way NPMANOVA) were performed using the PAST program package (Hammer et al., 2001) to test for differences in univariate measures (density, species richness and Shannon-Wiener diversity) of the mollusc assemblages among habitat types. Overall, differences in the associated assemblage structure were assessed using the habitat types as fixed factors (with five levels: main channel of River Danube, side channel of River Danube, tributary of River Danube, River Tisza, tributary of River Tisza), which included differences in individual species density. Before the one-way NPMANOVA analyses, all variables were normalized and a similarity matrix based on the Bray-Curtis coefficient was calculated. The NPMANOVAs were run among the five different levels using all species collected. $P$-values for the pseudo- $F$ ratios were calculated by permutation of raw data through 9999 permutations. Pairwise comparisons were also performed when appropriate. In addition, a SIMilarity PERcentages procedure (SIMPER) was used to assess the species contributing most to similarities within communities defined by the five main habitat types. In order to establish correlations between biotic and environmental data BIOENV analysis was performed using the Spearman coefficient. BIOENV analysis was done separately with only water chemistry data for all sites, and both water chemistry and sediment data only for sites in the main and side channels of the Danube. SIMPER and BIOENV analyses were performed using PRIMER v5 (Clarke and Warwick, 2001). 
To relate the species composition to environmental variables Redundancy Analysis (RDA) was performed using the software CaNOCO, version 4.5 (Ter Braak and Smilauer, 2002). Redundancy Analysis was done both for water chemistry and sediment characteristics in the main and side channels of the Danube. The length of the ordination gradient was tested by Detrended Correspondence Analysis (DCA). The gradient length of the DCA axis (tributaries: first axis: $2.773,2$. axis: $3.722,3-4$. axis: $<2$; Danube: first axis: 2.857, 2-4. axis: $<2$ ) suggested that the use of RDA is suitable for the data set. The most significant environmental variables were selected using the stepwise 'forward' selection procedure. An unrestricted random Monte Carlo permutation test was used to determine the significant abiotic effects and to verify the significance of the model.

\section{RESULTS}

In total 53 mollusc species and one bivalve variety (21 bivalves and 32 gastropods) were identified including 10 invasive species and 12 species of conservation concern (Table 1). Based on the cumulative species list, the five most widespread mollusc species were Unio tumidus (80\%), Pisidium amnicum (74.3\%), Lithoglyphus naticoides (74.3\%), Unio crassus (71.4\%), and Pisidium henslowanum $(65.7 \%)$. On the basis of relative abundances (number of individuals of the given species/total number of individuals) the five most abundant mollusc species were $L$. naticoides $(38.5 \%), P$. amnicum (9.1\%), Pisidium subtruncatum (6.9\%), Borysthenia naticina $(5.0 \%)$ and Valvata piscinalis (3.8\%, Table 1).

The contribution of endangered and rare species to the total density was highest in the tributaries of the Danube and in the main channel of the Tisza $(\sim 30 \%)$, and it was lowest in the main channel of the Danube (less than $10 \%$, Figure 2). The contribution of invasive species to the total density was highest in the main channel of the Danube and the Tisza $(\sim 20 \%)$, and it was lowest in the tributaries (less than 10\%, Figure 2).

Overall composition of the mollusc assemblages showed significant differences between habitat types $(P<0.0001, \mathrm{~F}=3.28)$. The density $(P<0.01$, $\mathrm{F}=3.91)$, number of species $(P<0.0001$, $\mathrm{F}=12.80)$ and Shannon-Wiener diversity $(P<0.01, \quad \mathrm{~F}=4.47) \quad$ also showed significant differences between habitat types (Figure 3 ). In pairwise comparisons, the overall composition and the number of species in almost every habitat differed from each other (Table 2), whereas the differences in density were caused mainly by the low values detected in the main channel of the Tisza, and the differences in the Shannon-Wiener diversity were caused mainly by the high values detected in the side channel of the Danube (Table 2, Figure 3).

In the main channel of the Tisza the average density, species richness, and Shannon diversity were 23.6 ind $\mathrm{m}^{-2}, 7.2$, and 2.2 , respectively. The assemblage was characterized by $U$. crassus, $U$ tumidus, Theodoxus fluviatilis, Unio pictorum, L. naticoides, Viviparus contectus and P. amnicum (Table 3).

In the tributary of the River Tisza (River Bodrog) the average density, species richness and Shannon diversity were 121.2 ind. $\mathrm{m}^{-2}, 11.0$ and 2.3, respectively. The assemblage was characterized by $L$. naticoides, $P$. amnicum, $U$. tumidus, U. crassus, B. naticina, Haitia acuta, $T$. fluviatilis and U. pictorum (Table 3).

In the side channels of the River Danube the average density, species richness, and Shannon diversity were 147.3 ind. $\mathrm{m}^{-2}, 26.2$ and 5.4, respectively. The assemblage was mainly characterized by $P$. subtruncatum, L. naticoides, $P$. henslowanum, Pisidium casertanum, Viviparus piscinalis, Bythinia tentaculata, $P$. amnicum, $U$. tumidus, Gyraulus albus and H. acuta (Table 3).

In the tributaries of the River Danube (rivers Ipoly and Rába) the average density, species richness and Shannon diversity were 71.8 ind. $\mathrm{m}^{-2}, 10.9$ and 2.9 , respectively. The assemblage was characterized by $P$. henslowanum, $U$. crassus, $P$. amnicum, Sphaerium corneum, $P$. nitidum, $U$. tumidus, U. pictorum, P. subtruncatum, Anodonta anatina, L. naticoides, Sphaerium rivicola and Pisidium supinum (Table 3).

In the main channel of the Danube the average density, species richness and Shannon diversity were 300.8 ind $\mathrm{m}^{-2}, 20.8$ and 3.7 , respectively. 
E. BÓDIS $E T A L$.

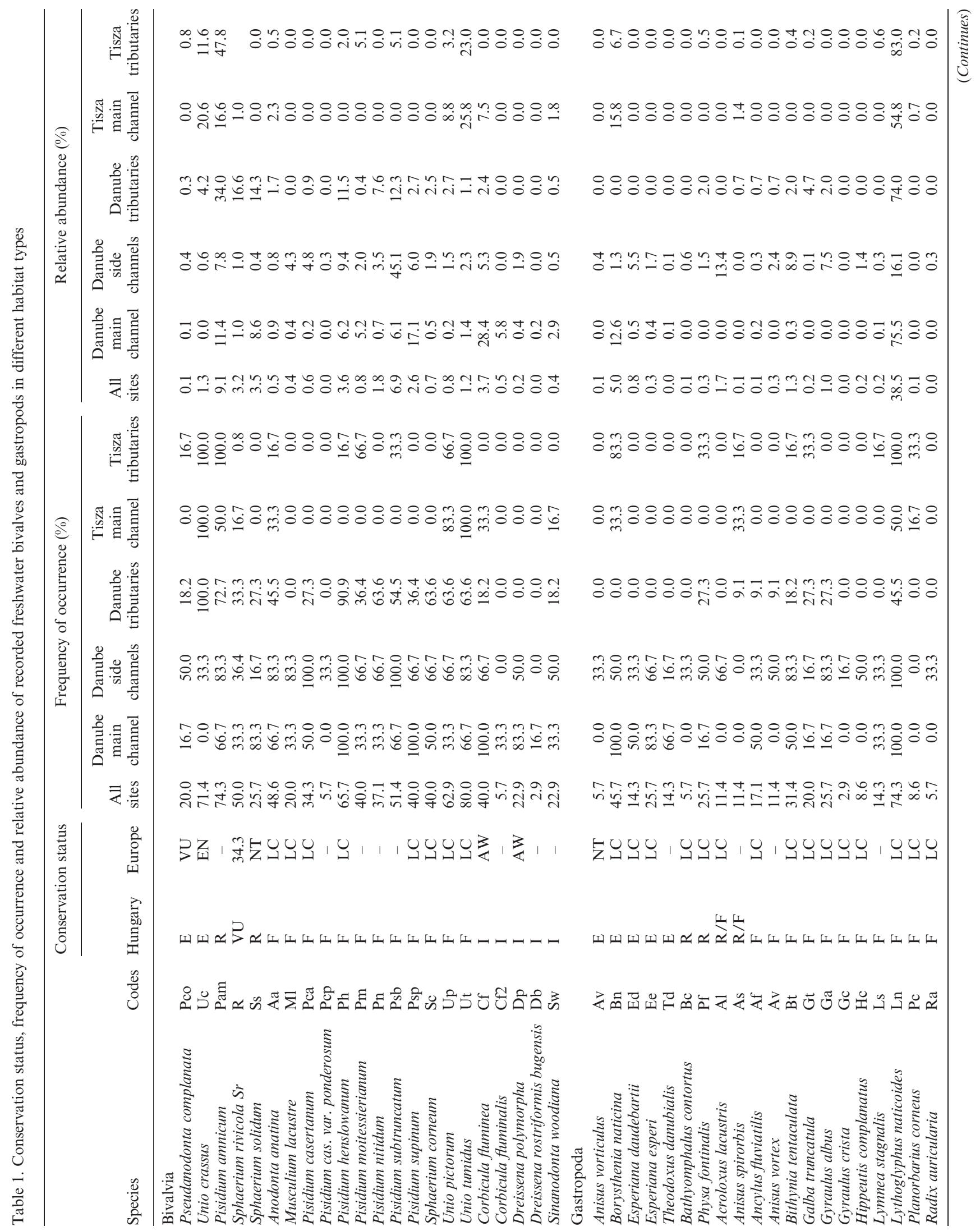


FRESHWATER MOLLUSC IN THE DANUBE RIVER DRAINAGE

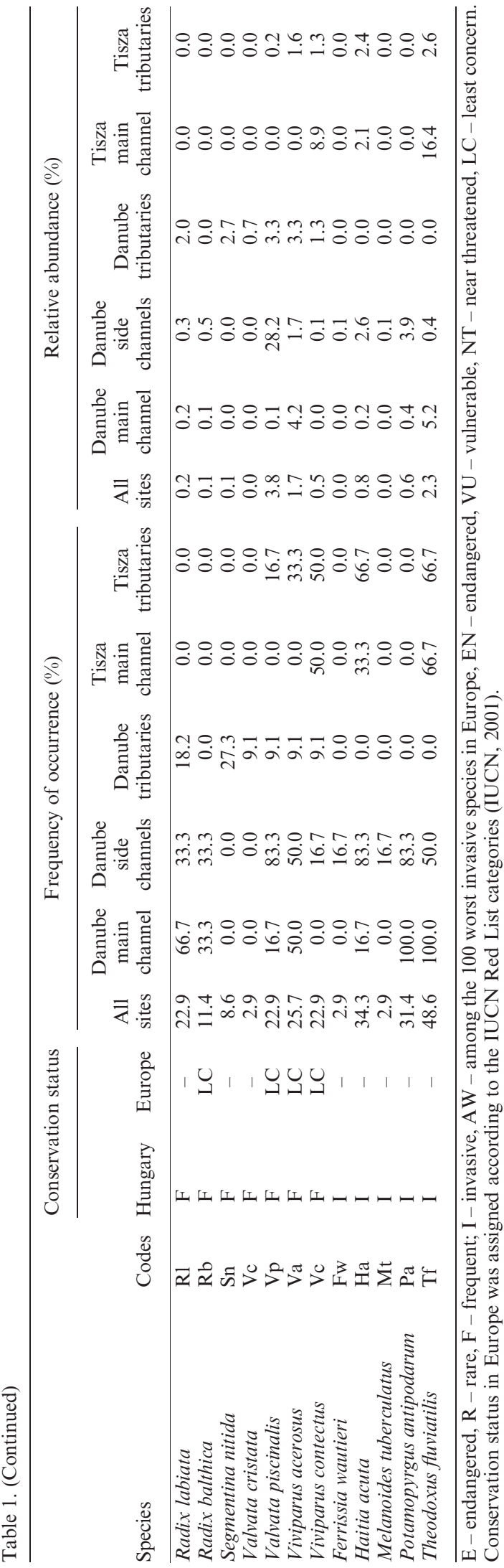

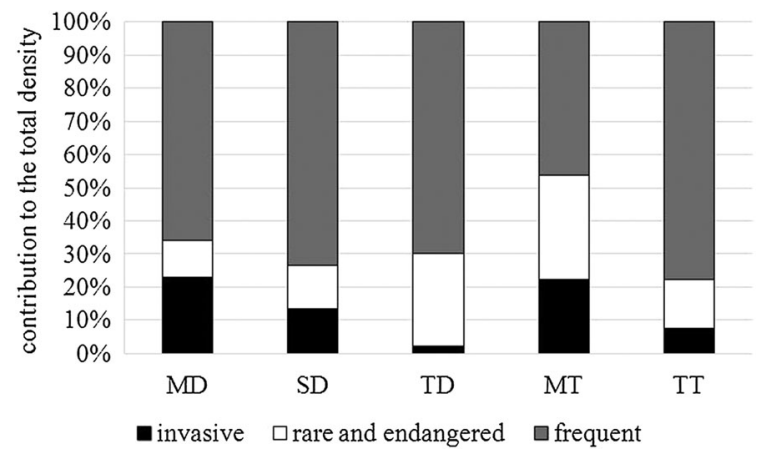

Figure 2. Percentage contribution of invasive, rare and frequent species to the total density according to habitat types (MD - Danube main channel, SD - Danube side channels, TD - Danube tributaries, MT Tisza main channel, TT - Tisza tributaries).

The assemblage was mainly characterized by L. naticoides, C. fluminea, T. fluviatilis, $B$. tentaculata, $P$. supinum, $P$. henslowanum, Sphaerium solidum, Potamopyrgus antipodarum, Dreissena polymorpha and Esperiana esperi (Table 3).

Significant differences in environmental parameters were not detected between the habitat types, but the highest conductivity, $\mathrm{PO}_{4}-\mathrm{P}, \mathrm{NH}_{4}-$ $\mathrm{N}$, and $\mathrm{NO}_{3}-\mathrm{N}$ content were observed in the tributaries of the Danube, the calcium content in the Tisza was half that of the Danube, and the $\mathrm{pH}$ and chlorophyll content was lowest in the tributary of the River Tisza (Table 4).

The BIOENV analysis based on the environmental variables measured only in the water column showed that the strongest explanatory factors with the highest correlation values were the $\mathrm{NO}_{3}-\mathrm{N}, \mathrm{NH}_{4}-\mathrm{N}$, oxygen and calcium content. On the other hand, on the basis of environmental variables measured both in the water column and in the sediment the strongest explanatory factors were the sedimenthological characteristics (coarse fraction of sediment, organic matter content of coarse and very fine fractions), the current velocity and the oxygen content (Table 5).

Based on the redundancy analyses (RDA) four of 17 environmental variables (coarse and fine fractions of sediment, organic matter content of ultra fine fraction and current velocity) were found to have a significant influence on the composition of the mollusc assemblages (Table 6, Figure 4). For the first and second axis the eigenvalues, the species-environment correlation, 

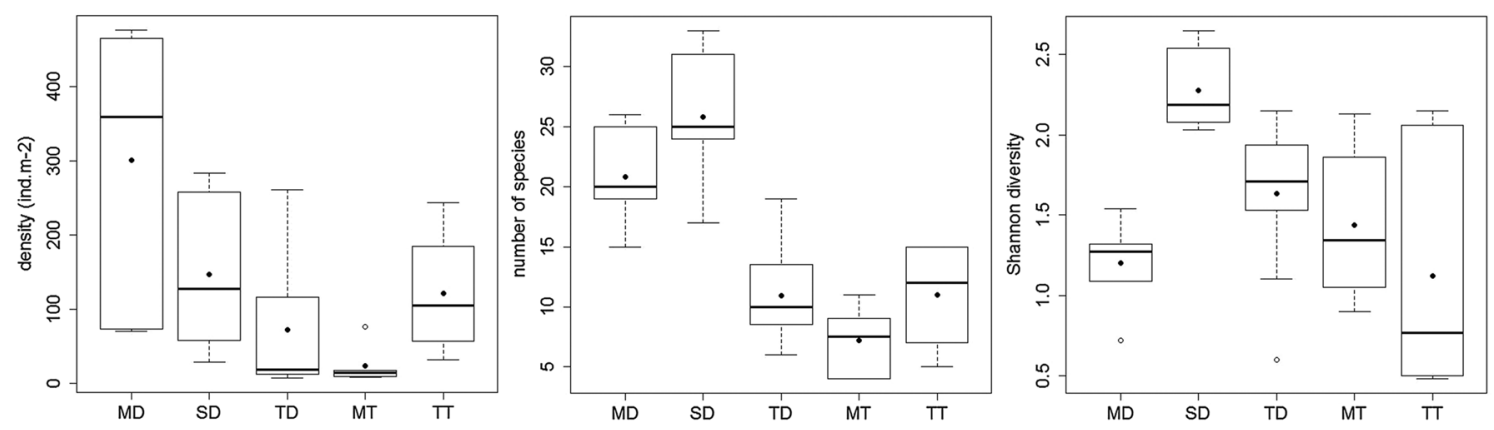

Figure 3. Density, number of species and Shannon diversity of molluscs according to habitat types (MD - Danube main channel, SD - Danube side channels, TD - Danube tributaries, MT - Tisza main channel, TT - Tisza tributaries).

Table 2. Pairwise comparisons of overall structure, density, number of species and Shannon diversity of mollusc assemblages in the Hungarian Danube River Drainage among habitat types (MD - Danube main channel, SD - Danube side channels, TD - Danube tributaries, MT - Tisza main channel, TT - Tisza tributaries). Only significant differences are shown

\begin{tabular}{|c|c|c|c|c|}
\hline & $\begin{array}{l}\text { Overall structure } \\
\qquad P<0.001\end{array}$ & $\begin{array}{l}\text { Density } \\
P<0.01\end{array}$ & $\begin{array}{l}\text { Number of species } \\
\qquad P<0.0001\end{array}$ & $\begin{array}{c}\text { Shannon diversity } \\
\qquad P<0.01\end{array}$ \\
\hline MD-SD & $P<0.01$ & - & - & $P<0.01$ \\
\hline MD-TD & $P<0.001$ & $P<0.05$ & $P<0.001$ & - \\
\hline MD-MT & $P<0.01$ & $P<0.01$ & $P<0.01$ & - \\
\hline MD-TT & - & - & $P<0.01$ & - \\
\hline SD-TD & $P<0.05$ & - & $P<0.001$ & $P<0.01$ \\
\hline SD-MT & $P<0.01$ & $P<0.01$ & $P<0.01$ & $P<0.01$ \\
\hline SD-TT & $P<0.01$ & - & $P<0.01$ & $P<0.01$ \\
\hline TD-MT & $P<0.01$ & - & $P<0.05$ & - \\
\hline TD-TT & $P<0.001$ & - & - & - \\
\hline MT-TT & $P<0.05$ & $P<0.01$ & - & - \\
\hline
\end{tabular}

the cumulative percentage variance of species data and the cumulative percentage variance of the species-environment relationship were 0.925 and $0.017 ; 0.993$ and $0.884 ; 92.50$ and $94.20 ; 97.00$ and 98.80, respectively. Eigenvalues of RDA axes were significant when tested with Monte Carlo permutations $(P<0.05)$. The first axis reflects the distribution of species in response to the sediment characteristics and organic matter content, while the second axis indicates the current velocity. The species located at the positive end of axis $1(P$. amnicum, Pisidium moitessierianum, $P$. henslowanum, $S$. rivicola, $S$. solidum, $L$. naticoides, $B$. naticina, Theodoxus danubialis and Radix balthica) preferred the ultrafine sediment fraction with high organic matter content. The species located towards the positive end of axis 2 (D. polymorpha, Dreissena bugensis, Ferrissia wauteri, Ancylus fluviatilis, E. esperi, Esperiana daudebartii, Galba truncatula, $C$. fluminea and $P$. supinum) were present preferentially in sites with high current velocity.

\section{DISCUSSION}

This study confirms the presence of diverse freshwater mollusc assemblages in the Hungarian Danube River Drainage and significant differences were detected among the distinct river habitat types. The highest di versity values were found in the side channels of the Danube, whereas the highest proportion of threatened species that contributed to the total density was observed in the tributaries of the Danube and Tisza. These results show that the low water flow, or almost lentic environment with a rich macrophyte community in side channels, provide an ideal habitat for high mollusc species richness and diversity. At the same time, invasive species are already present in the side channels and thus only the tributaries can provide effective refuge for threatened species.

Taking into consideration the relationship between freshwater mollusc species and environmental variables in a heterogeneous environment, which is characterized 
FRESHWATER MOLLUSC IN THE DANUBE RIVER DRAINAGE

Table 3. Average similarities for the mollusc groups defined by habitat types (MD - Danube main channel, SD - Danube side channels, TD - Danube tributaries, MT - Tisza main channel, TT - Tisza tributaries). Only species that altogether contribute with more than $90 \%$ total similarity are included

\begin{tabular}{|c|c|c|c|c|c|}
\hline & MT & $\mathrm{TT}$ & TD & SD & MD \\
\hline Unio crassus & 28.81 & 11.61 & 15.22 & - & - \\
\hline Unio tumidus & 25.30 & 12.46 & 5.75 & 4.32 & 2.05 \\
\hline Theodoxus fluviatilis & 13.03 & 4.77 & - & - & 10.29 \\
\hline Unio pictorum & 8.30 & 4.12 & 5.55 & 1.67 & - \\
\hline Lithoglyphus naticoides & 6.04 & 27.83 & 4.16 & 9.42 & 19.56 \\
\hline Viviparus contectus & 5.70 & - & - & - & - \\
\hline Pisidium amnicum & 3.70 & 16.23 & 9.50 & 4.34 & 3.07 \\
\hline Borysthenia naticina & - & 9.28 & - & - & 9.64 \\
\hline Haitia acuta & - & 4.83 & - & 3.69 & - \\
\hline Pisidium henslowanum & - & - & 18.69 & 7.82 & 5.31 \\
\hline Sphaerium corneum & - & - & 8.74 & 1.80 & - \\
\hline Pisidium nitidum & - & - & 8.41 & 2.54 & - \\
\hline Pisidium subtruncatum & - & - & 5.49 & 10.27 & 2.95 \\
\hline Anodonta anatina & - & - & 4.95 & 3.24 & - \\
\hline Sphaerium rivicola & - & - & 2.11 & - & - \\
\hline Pisidium supinum & _- & _- & 2.05 & 3.16 & 5.70 \\
\hline Pisidium casertanum & - & - & - & 6.56 & - \\
\hline Valvata piscinalis & - & - & - & 6.02 & - \\
\hline Bithynia tentaculata & _- & _- & _- & 5.32 & - \\
\hline Gyraulus albus & - & - & - & 3.78 & - \\
\hline Musculium lacustre & - & - & - & 3.54 & - \\
\hline Potamopyrgus antipodarum & - & - & - & 3.03 & 4.03 \\
\hline Acroloxus lacustris & - & - & - & 2.94 & - \\
\hline Corbicula fluminea & - & - & - & 2.29 & 10.43 \\
\hline Pisidium moitessierianum & - & - & - & 1.82 & - \\
\hline Esperiana esperi & - & - & - & 1.34 & 3.39 \\
\hline Anisus vortex & - & - & - & 1.26 & - \\
\hline Sphaerium solidum & - & - & - & - & 4.80 \\
\hline Dreissena polymorpha & - & - & - & - & 3.43 \\
\hline Theodoxus danubialis & - & - & - & - & 2.03 \\
\hline Radix labiata & - & - & - & - & 1.69 \\
\hline Viviparus acerosus & - & - & - & - & 1.67 \\
\hline
\end{tabular}

by variable substrate types and water flow conditions, that the main determining factors are the fractions and organic matter content of sediment, and the current velocity. These results are in accordance with previous studies, which showed that the habitat structure, heterogeneity and complexity are the most important factors affecting the composition of the mollusc assemblages (Sousa
Table 5. Combination of environmental variables giving the highest correlations (Spearman rank correlation) between biotic and environmental matrices using BIOENV analysis

\begin{tabular}{lc}
\hline Environmental variables & Correlation \\
\hline Water chemistry & \\
$\mathrm{NH}_{4}-\mathrm{N}, \mathrm{NO}-\mathrm{N}$ & 0.439 \\
$\mathrm{NO}_{3}-\mathrm{N}$ & 0.434 \\
$\mathrm{O}_{2}, \mathrm{NO}_{3}-\mathrm{N}, \mathrm{Ca}$ & 0.371 \\
$\mathrm{O}_{2}, \mathrm{NH}_{4}-\mathrm{N}, \mathrm{NO}_{3}-\mathrm{N}, \mathrm{Ca}$ & 0.358 \\
$\mathrm{O}_{2}, \mathrm{Ca}$ & 0.341 \\
Water chemistry and sediment characteristics & \\
$\mathrm{CBOM}, \mathrm{VBOM}$ & 0.462 \\
$\mathrm{CBOM}, \mathrm{VBOM}, \mathrm{O}_{2}$ & 0.451 \\
$\mathrm{CBOM}, \mathrm{VBOM}$, velocity & 0.447 \\
$\mathrm{CBOM}, \mathrm{VBOM}$, velocity, $\mathrm{O}_{2}$ & 0.443 \\
CBOM, VBOM, C & 0.440 \\
\hline
\end{tabular}

CBOM - coarse benthic organic matter.

VBOM - very fine benthic organic matter

et al., 2005, 2007; Eedy and Giberson, 2007; Gangloff and Feminella, 2007; Miserendino, 2009; Pérez-Quintero, 2012; Jurkiewicz-Karnkowska and Karnkowski, 2013). In addition, other environmental factors such as $\mathrm{NO}_{3}-\mathrm{N}, \mathrm{NH}_{4}-\mathrm{N}$, oxygen and calcium content of the water column were also important for determining the mollusc composition in this study. These results are consistent with several studies, which revealed that the high nitrate-nitrogen content exerts a negative impact on mollusc species richness and diversity, whereas the high oxygen and calcium content are essential for diverse and rich mollusc assemblages (Horsák and Hájek, 2003; Douda, 2007, 2009; Jurkiewicz-Karnkowska and Karnkowski, 2013). The majority of mollusc species preferred the low current velocity and sediments rich in organic matter, but some species are adapted to high water flow and coarse sediment fractions. In general, the successful invasive species (C. fluminea, $D$. polymorpha, D. bugensis and $T$. fluviatilis) can

Table 4. Average $( \pm S D)$ values of environmental variables of the water column according to habitat types (MD - Danube main channel, SD - Danube side channels, TD - Danube tributaries, MT - Tisza main channel, TT - Tisza tributaries)

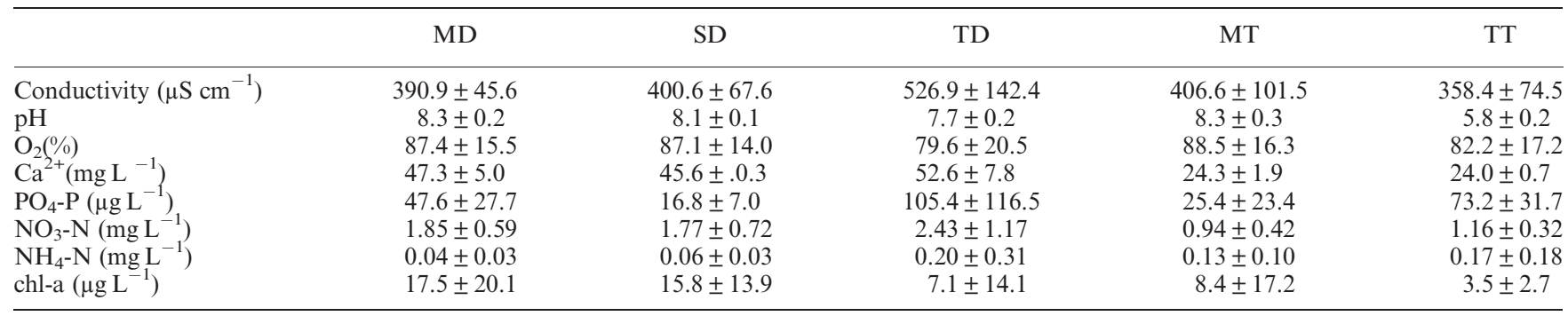


E. BÓDIS $E T A L$.

Table 6. Significant environmental variables defined by a Monte Carlo permutation test ( 999 permutations) in a forward selection procedure

\begin{tabular}{|c|c|c|c|c|c|}
\hline Environmental variable & Code & Variance $(\%)$ & Cumulative variance & $P$-value & F-value \\
\hline coarse benthic organic matter & $\mathrm{C}$ & 43.4 & 0.434 & 0.032 & 5.358 \\
\hline velocity & velo & 37.2 & 0.806 & 0.008 & 11.508 \\
\hline ultra fine benthic organic matter & UBOM & 1.2 & 0.954 & 0.012 & 4.646 \\
\hline
\end{tabular}

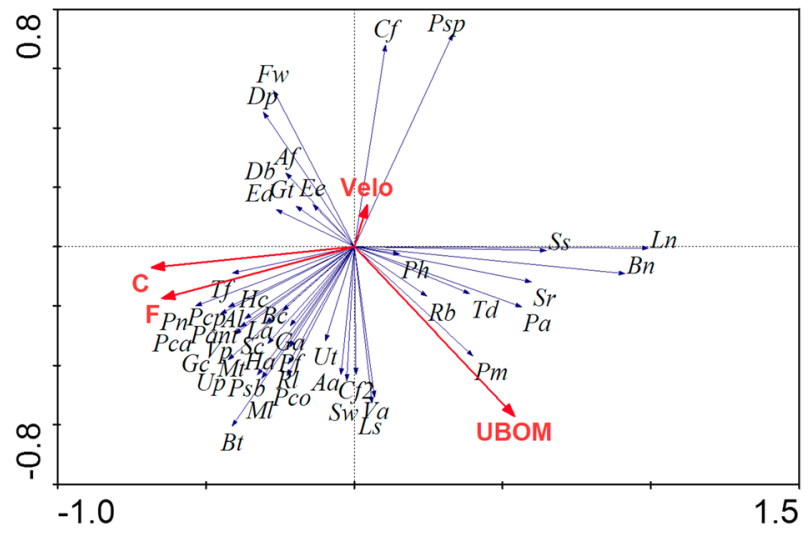

Figure 4. Redundancy analysis (RDA) of mollusc species, environmental variables and sampling sites. For codes of species see Table 1. For codes of environmental variables: see Table 6.

colonize habitats with variable conditions owing to their wider ecological tolerance and special adaptive abilities, whereas threatened species prefer less disturbed habitats because of their narrower ecological tolerance and sensitivity to human activites.

Although several of the species recorded are seriously threatened in Europe, only their distributions have been studied thoroughly (Varga and Csányi, 1997; Varga et al., 1998-1999; Varga and Uherkovich, 2002; Juhász et al., 2004, 2009; Bódis, 2008; Kovács et al., 2011, Horvai et al., 2012). Indeed, there is a general lack of data concerning basic ecological characteristics such as density, biomass and biotic and abiotic requirements for each species and the Hungarian Danube River Drainage is no exception. This kind of information is also lacking worldwide (Jones and Byrne, 2014; Lopes-Lima et al., 2014) although it should be the basis of effective conservation efforts.

The depressed river mussel (Pseudanodonta complanata) and the thick-shelled river mussel ( $U$. crassus) are threatened and classified as
'Vulnerable' and 'Endangered', respectively, by the IUCN Red List (IUCN, 2014). These species are also protected by national legislation in Hungary. Furthermore, U. crassus is listed in the Habitats Directive of the European Union (Annexes II and IV). A high density of $U$. crassus was recorded in the River Tisza and in the tributaries studied (for example in the River Ipoly-17.9 ind. $\mathrm{m}^{-2}$ ), but in the Danube this species had almost disappeared (recently only a few individuals have been found sporadically; Bódis, personal observation). Pseudanodonta complanata is found to be threatened in the Hungarian Danube River Drainage, since only a few individuals were detected in the water systems studied. Sphaerium rivicola and $S$. solidum are classified in the IUCN Red List as 'Vulnerable' and 'Near Threatened', respectively (IUCN, 2014). However, in the present study they were relatively frequent and $S$. solidum had high densities at certain sites. Anisus vorticulus has been listed in the EC Habitats Directive since 2004 (Annexes II and IV) and has been classified as 'Near Threatened' in the latest European assessment (IUCN, 2014). However, there is a lack of information across the eastern extent of its distribution and in the rivers studied only a few individuals were recorded in the Mosoni-Danube.

In addition to the species already mentioned, others are endangered in Hungary and protected by national legislation. Among these, $E$. daudebartii, E. esperi and $T$. danubialis were recorded only in the main and side channel of the Danube. Among species registered as rare in Hungary Bathyomphalus contortus occurred only in the side channel of the Danube, always with low density. However, other endangered (B. naticina) or rare species ( $P$. aminicum, Physa fontinalis) still have some large populations, mainly in tributaries. Although some species important for 
conservation, such as Theodoxus transversalis and Valvata macrostoma, were not recorded during this study, their presence in the Hungarian Danube River Drainage has been noted previously (Pintér and Suara, 2004; Kovács et al., 2011; Fehér et al., 2012).

Freshwater molluscs are threatened by human and climatic disturbances such as habitat loss, degradation and fragmentation, pollution, overexploitation, introduction of invasive species, droughts, and floods. The outcomes of these disturbances are responsible for alterations to channel characteristics, sedimentation processes, chemical composition, flow regime, habitat availability, and temperature and may modify important biotic interactions, which all have serious consequences for freshwater biota (Allan and Flecker, 1993; Mueller et al., 2011). In addition, these changes can affect fish species that serve as host organisms and vectors for the dispersal of freshwater mussels (Geist and Kuehn, 2005). The above-mentioned perturbations have a significant adverse effect both on bivalves (Layzer et al., 1993; Williams et al., 1993; Vaughn and Taylor, 1999; Aldridge, 2000; Poole and Downing, 2004; Newton et al., 2008; Babko and Kuzmina, 2009) and gastropods (Bogan, 2006; Tolley-Jordan et al., 2015) worldwide, and the Hungarian Danube River Drainage is no exception.

The rapid spread of invasive species is another threat to native molluscs and in the long term may contribute to the homogenization of the mollusc assemblages present in the Hungarian Danube River Drainage. The highest occurrence and density of invasive mollusc species were detected in the main channel of the Danube. Some of the invasive species recorded have already spread to the side channels and the adjacent wetland areas (Bódis et al., 2008), but most of them were not present in the tributaries surveyed. In the smaller rivers invasive species are restricted to areas close to the confluence with the rivers Danube and Tisza. However, $C$. fluminea and $S$. woodiana extended their range rapidly along the larger tributaries of the Danube in Bulgaria and the average dispersal rate of $C$. fluminea in the upstream direction was estimated to range between 5 and $8 \mathrm{~km}$ per year (Hubenov et al.,
2013). Some human activities such as fishing, fish stocking, recreational activities, and sand and gravel extraction may facilitate the establishment and spread of invasive species, and these activities deserve special attention. For example, a small population of $S$. woodiana was found in the River Ipoly, far from the confluence with the Danube, probably because of fish stocking activities. In addition, warm-water effluents can contribute to the aggregation of an extremely large biomass of thermophilic species, and serve as a thermal refuge for invasive species native to a warm climate and as a source of individuals for adjacent areas (Gollasch and Nehring, 2006; Galil et al., 2007). An extremely high density of $C$. fluminea, $C$. fluminalis and $S$. woodiana was observed at the outlet of the cooling water channel of Paks Nuclear Power Plant, which is an artificially modified habitat with water temperatures consistently $4-8^{\circ} \mathrm{C}$ higher than adjacent nondisturbed areas (Bódis et al., 2011).

Some of the invasive species, such as $C$. fluminea, $S$. woodiana and T. fluviatilis were widespread and abundant throughout the Hungarian Danube and Tisza and they may have adverse impacts on native fauna. For example, $C$. fluminea may compete with native bivalves owing to its high filtration ability (Strayer et al., 1999). At those sites in the River Danube where it attained high densities (736 ind. $\mathrm{m}^{-2}$ ), the population of rare species ( $S$. rivicola and $P$. amnicum) declined or disappeared (Bódis et al., 2011, 2012b). Theodoxus fluviatilis, which is abundant in the main channel of the Danube, may also have a negative impact on native Theodoxus species ( $T$. danubialis and $T$. transversalis), since these species have become very rare or have almost completely disappeared in the Danube (Fehér et al., 2012; Pavlova et al., 2013). Sinanodonta woodiana is a broad host generalist; its parasitic larval glochidia can develop both on native and invasive fish hosts in contrast to the native unionids, which are considered to have a limited number of host fish species (Douda et al., 2012a, b). Therefore, S. woodiana may decrease the chances for native unionids to find appropriate host organisms. Overall, the River Danube is an important invasion corridor contributing to the rapid spread of invasive species (Bódis et al., 
2012a), which may adversely affect several native mollusc species. However, most of these negative impacts are still speculative and further studies are needed to assess their real effects on native molluscs.

In conclusion, in the main channel of the Danube the presence of invasive species is high, while the occurrence of threatened native species is very low. In the side channels and the River Tisza the proportion of invasive and threatened native species is similar, but in future this ratio may shift towards invasive species, which may result in biodiversity loss and homogenization of the mollusc assemblages. Fortunately in the tributaries and some parts of the wetland areas the mollusc assemblages are still unharmed and several endangered species (for example $U$. crassus and $T$. transversalis) can still find suitable conditions (Juhász et al., 2009; Kovács et al., 2011; Fehér et al., 2012). Although species richness and diversity was highest in side channels, the proportion of threatened species was highest in tributaries. Tributaries may provide valuable habitats for threatened species and could be considered as 'source' populations that are critically important in the regional maintenance of threatened species. Based on some studies, the number of 'source' populations in a given area is a more relevant ecological criterion than species richness in the assessment of conservation value (Angermeier and Winston, 1997; JurkiewiczKarnkowska and Karnkowski, 2013). Consequently the protection and risk assessment of catchments connected with the River Danube are especially important and deserve conservation attention.

\section{ACKNOWLEDGEMENTS}

The study was supported financially by the Hungarian Scientific Research Fund under the contract No. OTKA T/046180 and No. CNK80140. Ronaldo Sousa acknowledges the financial support provided by the Portuguese Foundation for Science and Technology (FCT) and COMPETE funds - project ECO-IAS (Contract:PTDC/AAC-AMB/116685/2010). We are grateful to Edit Molnár, János Nosek, Nándor Oertel, Zsuzsanna Pohner, József Szekeres and the Danube-Ipoly National Park for their help in field work. Special thanks to Katalin Bodolai for help in the laboratory and creating map and Gábor Várbíró for providing environmental data.

\section{REFERENCES}

Aldridge D. 2000. The impacts of dredging and weed cutting on a population of freshwater mussels (Bivalvia: Unionidae). Biological Conservation 95: 247-257.

Alföldi L, Schweizer F. 2003. A Tisza vízrendszerének földrajzi és hidrológiai jellemzése. In A Tisza és vízrendszere, Teplán I (ed). MTA: Budapest; 41-52.

Allan JD, Flecker AS. 1993. Biodiversity conservation in running waters. Identifying the major factors that threaten destruction of riverine species and ecosystems. Bioscience 43: $32-43$.

Angermeier PL, Winston MR. 1997. Assessing conservation value of stream communities: a comparison of approaches based on centers of density and species richness. Freshwater Biology 37: 699-710.

Babko R, Kuzmina T. 2009. Effect of dams on hydrological parameters and the structure of benthic molluscs: case study in Dnieper river basin. Ecohydrology and Hydrobiology 9: 159-164.

Bódis E. 2008. Contribution to the macroinvertebrate fauna of the Hungarian Danube IV. Mussels (Bivalvia: Corbiculidae, Dreissenidae, Sphaeriidae, Unionidae). Folia Historico Naturalia Musei Matraensis 32: 57-68.

Bódis E, Nosek J, Oertel N. 2008. Spatio-temporal pattern of mussels (Corbiculidae, Dreissenidae, Sphaeriidae) in the water-system of the Hungarian Danube. Archiv für Hydrobiologie Supplement Large Rivers 18: 293-308.

Bódis E, Nosek J, Oertel N, Tóth B, Hornung E, Sousa R. 2011. Spatial distribution of bivalves in relation to environmental conditions (Middle Danube catchment, Hungary). Community Ecology 12: 210-219.

Bódis E, Borza P, Potyó I, Puky M, Weipert A, Guti G. 2012a. Invasive mollusc, crustacean, fish and reptile species along the Hungarian section of the River Danube and some connected waters. Acta Zoologica Academiae Scientiarum Hungaricae 58: 29-45.

Bódis E, Cs S, Tóth B, Oertel N, Nosek J, Hornung E. 2012b. Spatial and temporal variation in biomass and size structure of Corbicula fluminea in Middle Danube catchment, Hungary. Biologia (Bratislava) 67: 739-750.

Bódis E, Tóth B, Sousa R. 2014a. Massive mortality of invasive bivalves as a potential resource subsidy for the adjacent terrestrial food web. Hydrobiologia 735: 253-262.

Bódis E, Tóth B, Szekeres J, Borza P, Sousa R. 2014b. Empty native and invasive bivalve shells as benthic habitat modifiers in a large river. Limnologica 49: 1-9.

Bogan AE. 1993. Freshwater bivalve extinctions (Mollusca: Unionoidae): a search for causes. American Zoologist 33: 599-609.

Bogan AE. 2006. Conservation and extinction of the freshwater molluscan fauna of North America. In The Mollusks: A Guide to their Study, Collection, and Preservation, Sturm $\mathrm{CF}$, Pierce TA, Valdés A (eds). American Malacological Society: Pittsburgh; 374-383. 
Burlakova LE, Karatayev AY, Karatayev VA, May ME, Bennett DL, Cook MJ. 2011a. Biogeography and conservation of freshwater mussels (Bivalvia: Unionidae) in Texas: patterns of diversity and threats. Diversity and Distributions 17: 393-407.

Burlakova LE, Karatayev AY, Karatayev VA, May ME, Bennett DL, Cook MJ. 2011b. Endemic species: contribution to community uniqueness, effect of habitat alteration, and conservation priorities. Biological Conservation 144: 155-165.

Carpenter SR, Stanley EH, Vander Zanden MJ. 2011. State of the world's freshwater ecosystems: physical, chemical, and biological changes. Annual Review of Environment and Resources 36: 75-99.

Clarke KR, Warwick RM. 2001. Change in Marine Communities: An Approach to Statistical Analysis and Interpretation, 2nd edn.PRIMER-E Ltd., Plymouth Marine Laboratory: UK.

Douda K. 2007. The occurrence and growth of Unio crassus (Mollusca: Bivalvia: Unionidae) in Lužnice river basin in respect to water quality. Acta Universitatis Carolinae Environmentalica 21: 57-63.

Douda K. 2009. Effects of nitrate nitrogen pollution on Central European unionid bivalves revealed by distributional data and acute toxicity testing. Aquatic Conservation: Marine and Freshwater Ecosystems 20: 189-197.

Douda K, Horky P, Bíly M. 2012a. Host limitation of the thick-shelled river mussel: identifying the threats to declining affiliate species. Animal Conservation 15: 536-544.

Douda K, Vrtilek M, Slavik O, Reichard M. 2012b. The role of host specificity in explaining the invasion success of the freshwater mussel Anodonta woodiana in Europe. Biological Invasions 14: 127-137.

Dudgeon D, Arthington AH, Gessner MO, Kawabata ZI, Knowler DJ, Lévêque C, Naiman RJ, Prieur-Richard AH, Soto D, Stiassny MLJ, Sullivan CA. 2006. Freshwater biodiversity: importance, threats, status and conservation challenges. Biological Reviews 81: 163-182.

Eedy RI, Giberson DJ. 2007. Macroinvertebrate distribution in a reach of a north temperate eastern Canadian river: relative importance of detritus, substrate and flow. Archiv für Hydrobiologie 169: 101-114.

Falkner G, Bank RA, von Proschwitz T. 2001. Check-list of the non-marine molluscan species-group taxa of states of northern, atlantic and central Europe (CLECOM I). Heldia 4: 1-76.

Fehér Z, Gubányi A. 2001. Distribution of the Hungarian Molluscs, The Catalogue of the Mollusca Collection of the Hungarian Natural History Museum: Budapest.

Fehér Z, Majoros G, Varga A. 2006. A scoring method for the assessment of rarity and conservation value of the Hungarian freshwater molluscs. Heldia 6: 101-114.

Fehér Z, Albrecht C, Major Á, Sereda S, Krízsik V. 2012. Extremely low genetic diversity in the endangered striped nerite, Theodoxus transversalis (Mollusca, Gastropoda, Neritidae) - a result of ancestral or recent effects? North-Western Journal of Zoology 8: 300-307.

Galil BS, Nehring S, Panov V. 2007. Waterways as invasion highways - impacts of climate change and globalization. In Biological Invasions. Ecological Studies, Nentwig W(ed). Vol. 193, Springer: Berlin; 59-74.

Gangloff MM, Feminella JW. 2007. Stream channel geomorphology influences mussel abundance in southern Appalachian streams, USA. Freshwater Biology 52: 64-74.
Geist J, Kuehn R. 2005. Genetic diversity and differentiation of central European freshwater pearl mussel (Margaritifera margaritifera L.) populations: implications for conservation and management. Molecular Ecology 14: 425-439.

Gollasch S, Nehring S. 2006. National checklist for aquatic alien species in Germany. Aquatic Invasions 1: 245-269.

Gutiérrez JL, Jones CG, Strayer DL, Iribarne OO. 2003. Mollusks as ecosystem engineers: the role of shell production in aquatic habitats. Oikos 101: 79-90.

Hammer O, Harper DAT, Ryan PD. 2001. PAST: paleontological statistics software package for education and data analysis. Palaeontologia Electronica 4: 9.

Horsák M, Hájek M. 2003. Composition and species richness of molluscan communities in relation to vegetation and water chemistry in the Western Carpathian spring fens: the poor-rich gradient. Journal of Molluscan Studies 69: 349-357.

Horvai V, Czirok A, Lőkkös A, Borza P, Bódis E, Deák CS. 2012. New faunistic data from the riparian zone of the HungarianCroatian reach of Drava River. Acta Biologica Debrecina Supplementum Oecologica Hungarica 28: 109-120.

Hubenov Z, Trichkova T, Kenderov L, Kozuharov D. 2013. Distribution of Corbicula fluminea (Mollusca: Corbiculidae) over an eleven-year period of its invasion in Bulgaria. Acta Zoologica Bulgarica 65: 315-326.

IUCN. 2001. IUCN Red List Categories and Criteria: Version 3.1. IUCN Species Survival Commission. IUCN, Gland, Switzerland and Cambridge, UK.

IUCN. 2014. The IUCN Red List of Threatened Species. Version 2014.3. <http://www.iucnredlist.org $>$. Downloaded on 15 December 2014.

Jones HA, Byrne M. 2014. Changes in the distributions of freshwater mussels (Unionoida: Hyriidae) in coastal south-eastern Australia and implications for their conservation status. Aquatic Conservation: Marine and Freshwater Ecosystems 24: 203-217.

Juhász P, Kovács T, Ambrus A, Kavrán V. 2004. Data to the knowledge of the mollusc fauna living in the Hungarian segment of the River Tisza. Malacological Newsletter 22: 97-130.

Juhász P, Kiss B, Müller Z. 2009. Faunistical data to complete the nationwide occurrence of Thick Shelled River Mussel (Unio crassus Retzius, 1788). Folia Historico Naturalia Musei Matraensis 33: 53-59.

Jurkiewicz-Karnkowska E, Karnkowski P. 2013. GIS analysis reveals the high diversity and conservation value of mollusc assemblages in the floodplain wetlands of the lower Bug River (East Poland). Aquatic Conservation: Marine and Freshwater Ecosystems 23: 952-963.

Kovács K, Csányi B, Cs D, Kálmán Z, Kovács T, Szekeres J. 2011. Results of the Rába survey 2009 on aquatic macroinvertebrates I. Faunistical results. Acta Biologica Debrecina Supplementum Oecologica Hungarica 26: 135-151.

Layzer JB, Gordon ME, Anderson RM. 1993. Mussels: the forgotten fauna of regulated rivers - a case study of the Caney Fork River. Regulated Rivers: Research and Management 8: 63-71.

Lopes-Lima M, Teixeira A, Froufe E, Lopes A, Varandas S, Sousa R. 2014. Biology and conservation of freshwater bivalves: past, present and future perspectives. Hydrobiologia 735: 1-13.

Lydeard C, Cowie RH, Ponder WF, Bogan AE, Bouchet P, Clark SA, Cummings KS, Frest TJ, Gargominy O, Herbert 
DG, et al. 2004. The global decline of nonmarine molluscs. Bioscience 54: 321-330.

McAllister DE, Hamilton AL, Harvey B. 1997. Global freshwater biodiversity: striving for the integrity of freshwater ecosystems. Sea Wind - Bulletin of Ocean Voice International 11: 1-140.

Miserendino ML. 2009. Effects of flow regulation, basin characteristics and land-use on macroinvertebrate communities in a large arid Patagonian river. Biodiversity and Conservation 18: 1921-1943.

Mueller M, Pander J, Geist J. 2011. The effects of weirs on structural stream habitat and biological communities. Journal of Applied Ecology 48: 1450-1461.

Nosek J, Oertel N. 2008. Similarity patterns of macroinvertebrate communities in the Hungarian Danube and adjecent wetlands (Szigetköz and Gemenc). Archiv für Hydrobiologie Supplement Large Rivers 18: 243-256.

Nosek J, Vásárhelyi T, Bakonyi G, Oertel N. 2007. Spatial pattern of water bugs (Nepomorpha, Gerromorpha) at different scales in the Szigetk"oz (Hungary). Biologia (Bratislava) 62: 345-350.

Newton TJ, Woolnough DA, Strayer DL. 2008. Using landscape ecology to understand and manage freshwater mussel populations. Journal of North American Benthological Society 27: 424-439.

Pavlova M, Ihtimanska M, Dedov I, Biserkov V, Uzunov Y, Pehlivanov L. 2013. New localities of Theodoxus transversalis (C. Pfeiffer, 1828) within European Natura 2000 network on the islands of the Lower Danube River. Acta Zoologica Bulgarica 65: 121-123.

Pérez-Quintero JC. 2012. Environmental determinants of freshwater mollusc biodiversity and identification of priority areas for conservation in Mediterranean water courses. Biodiversity and Conservation 21: 3001-3016.

Pintér L, Suara R. 2004. Distribution of the Hungarian Molluscs II, The Catalogue of the Mollusca Collection of the Hungarian Natural History Museum: Budapest.

Poole KE, Downing DA. 2004. Relationship of declining mussel biodiversity to stream-reach and watershed characteristics in an agricultural landscape. Journal of North American Benthological Society 23: 114-125.

Régnier C, Fontaine B, Bouchet P. 2009. Not knowing, not recording, not listing: numerous unnoticed mollusk extinctions. Conservation Biology 23: 1214-1221.

Ricciardi A, Rasmussen JB. 1999. Extinction rates of North American freshwater fauna. Conservation Biology 13: $1220-1222$.

Rosemond AD, Mulholland PJ, Elwood JW. 1993. Top-down and bottom-up control of stream periphyton: effects of nutrients and herbivores. Ecology 74: 1264-1280.

Sousa R, Guilhermino L, Antunes C. 2005. Molluscan fauna in the freshwater tidal area of the River Minho estuary, NW of Iberian Peninsula. Annales de Limnologie - International Journal of Limnology 41: 141-147.

Sousa R, Antunes C, Guilhermino L. 2007. Species composition and monthly variation of the Molluscan fauna in the freshwater subtidal area of the River Minho estuary. Estuarine, Coastal and Shelf Science 75: 90-100.

Sousa R, Gutiérrez JL, Aldridge DC. 2009. Non-indigenous invasive bivalves as ecosystem engineers. Biological Invasions 11: 2367-2385.
Sousa R, Morais P, Dias E, Antunes C. 2011. Biological invasions and ecosystem functioning: time to merge. Biological Invasions 13: 1055-1058.

Sousa R, Novais A, Costa R, Strayer D. 2014. Invasive bivalves in fresh waters: impacts from individuals to ecosystems and possible control strategies. Hydrobiologia 735: 233-251.

Spooner DE, Vaughn CC. 2008. A trait-based approach to species' roles in stream ecosystems: climate change, community structure, and material cycling. Oecologia 158: $307-317$

Spooner DE, Vaughn CC, Galbraith HS. 2012. Species traits and environmental conditions govern the relationship between biodiversity effects across trophic levels. Oecologia 168: $533-548$.

Strayer DL. 2014. Understanding how nutrient cycles and freshwater mussels (Unionoida) affect one another. Hydrobiologia 735: 277-292.

Strayer DL, Dudgeon D. 2010. Freshwater biodiversity conservation: recent progress and future challenges. Journal of the North American Benthological Society 29: 344-358.

Strayer DL, Caraco NF, Cole JJ, Findlay S, Pace ML. 1999. Transformation of freshwater ecosystems by bivalves. BioScience 49: 19-27.

Ter Braak CJF, Smilauer P. 2002. CANOCO Reference manual and CanoDraw for Windows User's guide: Software for Canonical Community Ordination (ver. 4.5) Biometris, Wageningen and Ceské Budejovice.

Tolley-Jordan L, Huryn AD, Bogan AE. 2015. Effects of land-use change on a diverse pleurocerid snail assemblage. Aquatic Conservation: Marine and Freshwater Ecosystems. 25: 235-249.

Töry K. 1952. The River Danube and its Regulation, Budapest: Akadémiai Kiadó.

Varga A, Csányi B. 1997. Range data of water snails in the Hungarian rivers on the basis of research activity during the last decade. Folia Historico Naturalia Musei Matraensis 22: 285-322.

Varga A, Uherkovich Á. 2002. Malacological studies (Mollusca) in the Gemenc Landscape Protection Area of the Duna-Dráva National Park, South Hungary. Malacological Newsletter 20: 107-141.

Varga A, Csányi B, Majoros G. 1998-1999. Data on distribution of mussel species in Hungarian rivers based on faunal research of the last decade II. Folia Historico Naturalia Musei Matraensis 23: 347-367.

Vaughn CC, Hakenkamp CC. 2001. The functional role of burrowing bivalves in freshwater ecosystems. Freshwater Biology 46: 1431-1446.

Vaughn CC, Taylor CM. 1999. Impoundments and the decline of freshwater mussels: a case study of an extinction gradient. Conservation Biology 13: 912-920.

Vörösmarty CJ, McIntyre PB, Gessner MO, Dudgeon D, Prusevich A, Green P, Glidden S, Bunn SE, Sullivan CA, Liemann CR, Davies PM. 2010. Global threats to human water security and river biodiversity. Nature 467: $555-561$.

Williams JD, Warren ML, Cummings KS, Harris JL, Neves RJ. 1993. Conservation status of freshwater mussels of the United States and Canada. Fisheries 18: 6-22. 